\title{
Review of Sustainable Energies Use in Greenhouses in Greece
}

\author{
John Vourdoubas \\ Mediterranean Agronomic Institute of Chania, Agrokipio, 73100, \\ Chania, Crete, Greece. E-mail: vourdoubas@maich.gr
}

Received: March 1, 2018

Accepted: March 20, 2018

doi:10.5296/jas.v6i2.12973

URL: https://doi.org/10.5296/jas.v6i2.12973

\begin{abstract}
Greenhouses consume large amounts of energy compared with other agricultural activities contributing to environmental pollution. However the current advances in sustainable energy technologies allow the use of benign energy sources for heat and power generation in them. Various renewable and high efficiency energy technologies are currently used in Greece or could be used in the near future in them. The technologies are mature, reliable and cost-effective. Among them the direct geothermal energy, solid biomass, solar-PV, waste heat re-use and co-generation of heat and power. Their use in small or larger greenhouses reduces the environmental pollution due to fossil fuels use, lowers the dependence on imported fuels, promote investments and create jobs in the local societies. Currently modern hydroponic greenhouses in northern Greece use co-generation of heat and power systems fuelled with natural gas. Heat is used in the greenhouses and the generated power is fed into the grid. Others utilize direct geothermal fluids for space heating. Solid biomass is also used for heating them. All of them can cover all the heating needs in greenhouses. Industrial rejected heat from lignite fired power plants in northern Greece could be easily used in the future for heating them. At the same time the high solar irradiance allows the use of solar photovoltaic (PV) systems for power generation in them. Further integration of sustainable energies in greenhouses in Greece requires the governmental support both in the form of financial subsidies and in removing the existing barriers preventing their use.
\end{abstract}

Keywords: biomass, co-generation, geothermal energy, Greece, greenhouses, solar-PV, sustainable energies, waste heat re-use.

\section{Introduction}

Greenhouses are among the most energy intensive production systems in agriculture. Maintenance of appropriate indoor conditions required for plants growth increases the crop productivity and quality. Improvement of their energy sustainability requires the increased 
use of renewable energies and low carbon technologies. The replacement of fossil fuels use in greenhouses with benign energy sources will assist in the achievement of three very important goals that our societies have set in the beginning of the $21^{\text {st }}$ century in order to mitigate climate change. The decrease of fossil fuels use and $\mathrm{CO}_{2}$ emissions and the increase of the share of renewables in the total energy mix. Higher use of sustainable energies in greenhouses depend on their maturity and reliability, on their cost effectiveness as well as on the appropriate governmental policies and incentives promoting their use.

\subsection{Use of direct geothermal energy in greenhouses}

Bakos et al, 1999 have reported on a greenhouse heated with geothermal energy located in northern Greece. The temperature of the geothermal fluid was at $95^{\circ} \mathrm{C}$ and the heating system was able to maintain an indoor temperature at $20^{\circ} \mathrm{C}$ when the outside was at $7^{\circ} \mathrm{C}$. Another greenhouse used for strawberries cultivation was heated with a different geothermal fluid at $50^{\circ} \mathrm{C}$ maintaining the indoor temperature at $15^{\circ} \mathrm{C}$. The authors stated that circulation of warm water in plastic pipes placed on the ground among the plants consists of a very efficient heating method. Papachristou et al, 2016 have reported on geothermal energy use in agricultural greenhouses in Greece. The authors have mentioned the heating of a hydroponic greenhouse producing tomatoes covering 8.2 hectares (ha) located in northern Greece with geothermal energy. The average temperature of the geothermal fluid used for heating was at $60^{\circ} \mathrm{C}$. They also stated that in March 2016 there were nineteen (19) greenhouses operating in continental Greece and in the islands of Milos and Lesvos which were heated with direct geothermal energy. Esen et al, 2013 have reported on experimental evaluation of using various renewable energy sources for heating a greenhouse in Turkey. The authors have experimented with a heating system using a ground source heat pump. They concluded that ground source heat pump systems are very efficient in heating and cooling agricultural greenhouses. Santamouris et al, 1995 have reported on using low enthalpy geothermal energy for cooling greenhouses. The authors have indicated that earth to air heat exchangers with underground buried pipes could be used for cooling them. They estimated that the investment cost of the proposed cooling system represents about 5\% of the total investment cost and the energy consumption during its operation represents approximately $8 \%$ of the cooling energy supplied by this system.

\subsection{Use of industrial waste heat in greenhouses}

Vourdoubas, 2018 has reported on the possibilities of using industrial waste heat for heating greenhouses in northern Greece. The author has indicated that the waste heat from the lignite fired power plants, which is currently used for district heating in few Greek towns in northern Greece, could be also used for heating modern agricultural greenhouses in this area. Maare, 1992 has reported on economical heat supply of greenhouses experience from Denmark. The author has described an energy cooperative which was utilizing the heat rejected from a power plant for heating greenhouses in a nearby area. He stated that the system operated satisfactory obtaining an indoor temperature at $19^{\circ} \mathrm{C}$. Bredenbeck, 1992 has reported on the waste heat re-use from a power plant in Germany for greenhouse heating. The greenhouse area was 53 ha and the temperature of the water rejected stream was $30^{\circ} \mathrm{C}$ in winter and $40^{\circ} \mathrm{C}$ 
in summer. The author has stated that the heating system was able to keep an indoor temperature at $22^{\circ} \mathrm{C}$ while the outdoor temperature was minus $14^{\circ} \mathrm{C}$. Manning et al, 1983 have reported on the heating of a 1.1 ha agricultural greenhouse located in Pennsylvania, USA, heated with condenser discharge water from the Pennsylvania power station. The authors have stated that the average temperature of the discharged water was at $30^{\circ} \mathrm{C}$ and satisfactory heating of the greenhouse was achieved with indoor temperature at $18^{\circ} \mathrm{C}$.

\subsection{Heating greenhouses with woody biomass}

Bibbiani et al, 2016 have presented a report on wood biomass use for heating greenhouses in Italy. The authors have estimated that the power loads in greenhouses vary from $30 \mathrm{~W} / \mathrm{m}^{2}$ in southern regions up to $175 \mathrm{~W} / \mathrm{m}^{2}$ in northern regions. They have also estimated that the annual energy consumption for heating varies from 21 to $546 \mathrm{KWh}_{\mathrm{th}} / \mathrm{m}^{2}$ depending on the desired indoor temperatures. The authors stated that $\mathrm{CO}_{2}$ enrichment from the exhaust gases of biomass boilers is still challenging but expensive due to their necessary cleaning. A techno-economic analysis of wood biomass boilers for the greenhouse industry has been reported from Chau et al, 2009. The authors have investigated the economic feasibility of using solid biomass for heating greenhouses in Canada. They have compared a $5 \mathrm{MW}$ wood boiler heating a 7.5 ha greenhouse providing $40 \%$ of its annual heat demand with a natural gas boiler. The authors estimated the net present value (NPV) of the investment and they concluded that the wood biomass boiler was profitable and desirable having positive NPVs. A review of $\mathrm{CO}_{2}$ recovery methods from the exhaust gas of biomass heating systems for safe enrichment in greenhouses has been published by Dion et al, 2011. The authors have investigated the possibility of using flue gases from landfill biogas and solid biomass burning in greenhouses. They have indicated that instead of combustion, biomass gasification produces syngas. Syngas burning produces exit gases which could be used for enrichment of the greenhouse atmosphere. Pollutants in exhaust gases from solid biomass burning could be also removed either by membrane separation or with wet scrubbing systems but their cost is rather high. Campiotti et al, 2012 have reported on sustainable greenhouses in Europe. The authors have stated that heating loads in greenhouses vary from $50-150 \mathrm{~W} / \mathrm{m}^{2}$ in southern regions of Europe to $200-280 \mathrm{~W} / \mathrm{m}^{2}$ in northern and central regions while total energy loads could reach $400 \mathrm{~W} / \mathrm{m}^{2}$. The authors, with reference in Italy, proposed that various renewable energy sources including solid biomass boilers, solar-PV systems and geothermal heat pumps could be used in greenhouses. Additionally very efficient co-generation heat and power systems could be also used. An economic evaluation of biomass heating systems for greenhouses in Greece has been reported by Gousgouriotis et al, 2007. The authors have stated that the initial cost of biomass burning systems is higher than the cost of conventional heating systems. In the case though that the biomass cost is low, it counterbalances the high investment cost and its use could be highly profitable. A case study of a greenhouse located in Crete, Greece which covers all its heating needs with solid biomass has been published by Vourdoubas, 2015. The author has described an agricultural greenhouse using as fuel olive kernel wood, a locally produced solid biomass source by-product of the olive oil industry. He stated that the indoor air temperature was kept at $19^{\circ} \mathrm{C}$ and its annual heat energy consumption was $220 \mathrm{KWh} / \mathrm{m}^{2}$. An overview of the use of sustainable energies in agricultural 
greenhouses has been reported by Vourdoubas, 2016. The author has presented current and possible future applications of renewable energies as well as other sustainable energy technologies in greenhouses. Those included solar thermal energy, solar-PV, wind energy, solid biomass, biogas, direct geothermal energy, geothermal heat pumps, co-generation of heat and power, waste heat re-use and fuel cells. He concluded that currently there are worldwide various greenhouses using successfully renewable energies and low carbon energy technologies. Kittas et al, $\mathbf{2 0 0 2}$ have reported on greenhouse heating with solid biomass in Magnesia prefecture in central Greece. The authors have stated that the power of the heating systems used in greenhouses varies from $90 \mathrm{~W} / \mathrm{m}^{2}$ to $170 \mathrm{~W} / \mathrm{m}^{2}$ for maintaining the indoor air temperatures at $10^{\circ} \mathrm{C}$ to $18^{\circ} \mathrm{C}$. They have also found that $84 \%$ of the heating energy used in greenhouses in this area has been produced by fossil fuels and the rest $16 \%$ from solid biomass, while $88 \%$ of the solid biomass used was olive kernel wood and the rest $12 \%$ was almond shells.

\subsection{Use of co-generation of heat and power systems in greenhouses}

Hydroponic greenhouses producing tomatoes in northern Greece which are heated with heat produced with a co-generation of heat and power (CHP) system fuelled with natural gas have been reported (http://www.agritex.gr/),(https://www.wonderplant.gr/en/company/).Heat is used in the greenhouse while the co-generated electricity is sent into the grid and the exhaust gases after their cleaning are enriching the inside atmosphere increasing the photosynthetic activity of the plants. The economic feasibility of co-generation systems used in greenhouses has been investigated by Compernolle et al, 2011. The authors have stated that high efficiency CHP systems could reduce the carbon footprint of the agricultural sector. Implementing two case studies in two greenhouses growing tomatoes and lettuces they indicated that the CHP systems with power $239 \mathrm{KW}$ and $1.2 \mathrm{MW}$ are economically viable having positive NPVs. Evaluation of the feasibility of alternative energy sources for greenhouse heating has been reported by Garcia et al, 1998. The authors have compared four (4) greenhouse heating systems with computer simulation techniques including a conventional heating system, a co-generation system, a heat pump and flat plate solar collectors. The authors stated that flat solar collectors are not appropriate for greenhouse heating with current fuel prices. Heat pumps could be economically viable in northern European countries while CHP systems were found to be more attractive for greenhouse heating.

\subsection{Use of solar-PV systems in greenhouses}

Marucci et al, 2012 have reported on the use of semi-transparent photovoltaic films for Mediterranean greenhouses. The authors have investigated the performance of semi-transparent PV films used as covering material in the greenhouses. They stated that the PV film reduces the photosynthetic process in the plants and it also reduces the thermal infrared losses. Tudisca et al, 2013 have studied the Italian policy regarding photovoltaic investments on greenhouses. The authors have studied the profitability of a Sicilian farm that has installed PV panels on its greenhouses according to feed-in tariffs regulations. They concluded that the solar-PV system was very profitable due to attractive feed-in tariffs. In fact 
the energy revenues were higher than the revenues from the farming activities. Vourdoubas, 2016 has investigated the possibilities of using semi-transparent PV panels on rooftops of greenhouses in Crete, Greece. The author estimated that if the semi-transparent PV modules will cover approximately $50 \%$ of their surface, the incoming irradiance would be enough to support the growth of the plants. He concluded that in a greenhouse of $1,000 \mathrm{~m}^{2}$, a solar-PV system with nominal power of $42.5 \mathrm{KWp}$ would be able to cover the most of its energy needs or even sell the electricity surplus into the grid.

Objectives of the current work include:

a) Presentation of various sustainable energy technologies which are currently used in agricultural greenhouses in Greece including direct geothermal energy, solid biomass and co-generation of heat and power systems,

b) Presentation of various sustainable energy technologies which could be used in the future in greenhouses in Greece including industrial waste heat re-use and solar-PV systems, and

c) Assessment of the advantages and drawbacks of the abovementioned sustainable energy technologies used for heating greenhouses.

\section{Use of solid biomass for heating greenhouses in Greece}

Solid biomass is currently used for heating greenhouses in Greece and various types of locally produced solid biomass are used for that. In regions with olive trees cultivation a by-product of the olive processing industry, the olive kernel wood, is an attractive fuel for heating greenhouses. Its excellent burning characteristics and, taking into account its energy content, its low price compared with the price of traditional fuels have increased its attractiveness in the greenhouse industry. The energy content of the olive kernel wood is approximately $4,000 \mathrm{Kcal} / \mathrm{kg}$, at $12 \%$ moisture content, and its current price in Greece is 0.10 $€ / \mathrm{kg}$. In other regions producing peaches or apricots their kernels are also used as heating fuel in greenhouses. Solid biomass heating is mainly used in small size greenhouses with covered area less than 0.4 ha. However the cost of solid biomass boilers is higher than the cost of boilers using conventional fuels. They also need regular maintenance and their operation can be automated satisfactorily. State subsidies to greenhouse owners who invest in solid biomass boilers counterbalance their higher capital and maintenance cost. Solid biomass burning produces exhaust gases which need processing for the removal of undesired pollutants. Use of appropriate cleaning systems increases the cost of biomass heating. However in small greenhouse installations which are located in remote areas processing of the flue gases is not necessary. Recycle of the $\mathrm{CO}_{2}$ contained in the exhaust gases for the enrichment of the greenhouse atmosphere is not currently used due to high cost of gas cleaning. Solid biomass heating can cover all the annual heating needs of modern greenhouses. Apart from solid biomass, biogas produced in landfills could be used for greenhouse heating although there are not currently such applications in Greece. The advantages and drawbacks of biomass heating are presented in table 1 . 
Table 1. Advantages and drawbacks of greenhouse heating with solid biomass.

\begin{tabular}{|l|l|}
\hline Advantages & Drawbacks \\
\hline $\begin{array}{l}\text { Solid biomass is a renewable energy } \\
\text { source produced locally in many areas }\end{array}$ & $\begin{array}{l}\text { Its burning produces flue gases which need } \\
\text { cleaning }\end{array}$ \\
\hline $\begin{array}{l}\text { Its price taking into account its heating } \\
\text { value is low compared with traditional } \\
\text { fuels }\end{array}$ & $\begin{array}{l}\text { The cost of a biomass boiler is higher than the cost } \\
\text { of a boiler using conventional fuels }\end{array}$ \\
\hline $\begin{array}{l}\text { The investment cost of biomass heating } \\
\text { systems in greenhouses is subsidized }\end{array}$ & $\begin{array}{l}\text { Maintenance cost of the heating system is higher } \\
\text { that the corresponding cost of systems using } \\
\text { conventional fuels }\end{array}$ \\
\hline $\begin{array}{l}\text { It could cover all the heating needs of a } \\
\text { modern greenhouse }\end{array}$ & $\begin{array}{l}\text { Usually a dry place for solid biomass storage is } \\
\text { required }\end{array}$ \\
\hline $\begin{array}{l}\text { Solid biomass use increases the } \\
\text { employment in local societies }\end{array}$ & $\begin{array}{l}\text { Its use reduces the use of fossil fuels } \\
\text { and the net } \mathrm{CO}_{2} \text { emissions }\end{array}$ \\
\hline $\begin{array}{l}\text { Its use decreases the dependence of a } \\
\text { country on imported fossil fuels }\end{array}$ & \\
\hline
\end{tabular}

\section{Direct geothermal energy use in greenhouses}

Geothermal energy is currently used for heating greenhouses in Greece. Warm geothermal water at $40-60{ }^{\circ} \mathrm{C}$ can be circulated inside plastic pipes placed on the ground among the plants obtaining their satisfactory heating. If the temperature of the geothermal fluid is higher than $60{ }^{\circ} \mathrm{C}$ the use of a heat exchanger is necessary. Depending on the flow rate and the temperature of the geothermal fluid it can be used for heating smaller or larger greenhouses. In the case that the geothermal fluid contains salts or other undesired pollutants their removal is necessary and the geothermal fluid is usually re-injected in a nearby well after its use. If the geothermal spring is located nearby the greenhouses the transport cost of the geothermal fluid is low. Low enthalpy geothermal energy at temperatures $40-90{ }^{\circ} \mathrm{C}$ can cover all the heating needs of modern greenhouses and there are currently many such applications all over the world. Apart from the direct use of low enthalpy geothermal energy for heating greenhouses it can be used indirectly with ground source heat pumps for their heating and cooling. Heat pumps though are expensive equipment using electricity as power source having high efficiencies, with coefficients of performance in the range 2.5-5. There are broadly used to day for heating and cooling buildings as well as in industry but their economically feasibility for heating and cooling greenhouses in Mediterranean region has not been proved yet. Applications of cooling greenhouses with an underground heat exchanger in Greece have not been reported so far although the experimental results are encouraging. The advantages and drawbacks for heating greenhouses with direct geothermal energy are presented in table 2 . 


\section{Macrothink}

Table 2. Advantages and drawbacks for heating greenhouses with direct geothermal energy.

\begin{tabular}{|l|l|}
\hline Advantages & Drawbacks \\
\hline $\begin{array}{l}\text { There is no cost of fuel. Costs are only } \\
\text { related with the transport cost of the } \\
\text { geothermal fluid, its pumping cost from } \\
\text { underground reservoirs if necessary and } \\
\text { pollutants removal cost if necessary. }\end{array}$ & $\begin{array}{l}\text { lt be only used in greenhouses } \\
\text { located in nearby sites to geothermal } \\
\text { reservoirs. }\end{array}$ \\
\hline $\begin{array}{l}\text { All the heating needs of greenhouses can } \\
\text { be covered. }\end{array}$ & $\begin{array}{l}\text { In some cases the removal of undesired } \\
\text { pollutants is necessary and it could be } \\
\text { costly. }\end{array}$ \\
\hline $\begin{array}{l}\text { There is long experience using this } \\
\text { technology with positive results. }\end{array}$ & $\begin{array}{l}\text { The investment cost of these heating } \\
\text { systems is usually subsidized. }\end{array}$ \\
\hline $\begin{array}{l}\text { The operating cost of the heating system } \\
\text { is low. }\end{array}$ & $\begin{array}{l}\text { Their use reduces the carbon emissions } \\
\text { due to energy use. }\end{array}$ \\
\hline
\end{tabular}

\section{Use of co-generation of heat and power systems in greenhouses}

CHP systems can be used in greenhouses. Existing systems in Greece are mainly fuelled with natural gas obtaining high overall efficiencies in the range of $85-90 \%$ and lower emissions of pollutants compared with the use of other fossil fuels. Generated electricity is fed into the grid with satisfactory financial compensation and the co-produced heat is used for heating. During the summer when cooling, rather than heating, is needed in the greenhouse heat can be used for cooling production with absorption cooling systems. Exhaust gases from natural gas burning can be used after appropriate cleaning for enrichment of the greenhouse atmosphere increasing the crop's productivity. Installation of a CHP system in a greenhouse results in increased revenues, due to electricity generation, additional to the crop's income. CHP in greenhouses can be fuelled with solid biomass, resulting in zero net carbon emissions, although such systems have not been reported so far in Greece. These systems can cover all the heating needs in greenhouses. However their use is more attractive in large scale greenhouses and currently two modern hydroponic greenhouses in Greece are using CHP systems [http://www.agritex.gr/], [https://www.wonderplant.gr/en/company/]. The installation cost of such systems in greenhouses is high but it is subsidized by the Greek government. The advantages and drawbacks for using CHP systems in greenhouses are presented in table 3. 


\section{Macrothink}

Table 3. Advantages and drawbacks of using CHP systems in greenhouses.

\begin{tabular}{|l|l|}
\hline Advantages & Drawbacks \\
\hline $\begin{array}{l}\text { Generated heat can cover all heating } \\
\text { needs in greenhouses }\end{array}$ & The capital cost of CHP systems is high \\
\hline $\begin{array}{l}\text { Co-generated electricity can be sold into } \\
\text { the grid offering additional income to the } \\
\text { growers }\end{array}$ & $\begin{array}{l}\text { The CHP systems are suitable for large } \\
\text { greenhouses }\end{array}$ \\
\hline $\begin{array}{l}\text { Exhaust gases from natural gas burning } \\
\text { can be recycled into the greenhouse } \\
\text { atmosphere }\end{array}$ & $\begin{array}{l}\text { If the CHP system is fuelled with fossil } \\
\text { fuels greenhouses gases and other } \\
\text { pollutants are emitted }\end{array}$ \\
\hline $\begin{array}{l}\text { Investment costs are subsidized by the } \\
\text { government }\end{array}$ & $\begin{array}{l}\text { If natural gas is used, emission of } \\
\text { pollutants would be lower compared with } \\
\text { the use of other fossil fuels. }\end{array}$ \\
\hline
\end{tabular}

\section{Waste heat re-use for heating greenhouses}

Rejected heat, mainly from power plants, can be used for heating greenhouses. Lignite is extensively used for electricity generation in Greece and currently the cooling water streams from those power plants are used for district heating in few towns in northern Greece. Likewise the district heating of buildings, industrial waste heat could be used for heating greenhouses covering all their heating needs. The area of the greenhouse which could be heated depends on the temperature and the flow rate of the cooling water stream. If the cooling water temperature is approximately $40-60{ }^{\circ} \mathrm{C}$ it could be directly used for heating greenhouses circulating inside plastic pipes placed on the ground. The cost of greenhouse heating is related only with the transport cost of the cooling water stream. Since the industry will avoid the disposal of the cooling water into a reservoir and the subsequent processing cost probably it would not charge the heat energy if a greenhouse wants to use it. Rejected heat re-use in greenhouses reduces carbon emissions in the atmosphere. However such applications have not been reported so far in Greece although it could be used in the future since waste heat is currently used for heating buildings and the technology is well proven, mature and reliable. The advantages and drawbacks of the waste heat re-use in heating greenhouses are presented in table 4. 


\section{Macrothink}

Table 4. Advantages and drawbacks for heating greenhouses with rejected heat.

\begin{tabular}{|l|l|}
\hline Advantages & Drawbacks \\
\hline There are not any pollutants emissions & $\begin{array}{l}\text { The greenhouse must be located nearby } \\
\text { the power plant in order to minimize the } \\
\text { distance and the cost of transport of the } \\
\text { cooling water stream. }\end{array}$ \\
\hline $\begin{array}{l}\text { All the heating needs of the greenhouse } \\
\text { could be covered }\end{array}$ & \\
\hline $\begin{array}{l}\text { There is not any thermal pollution of } \\
\text { reservoirs with the disposal of the cooling } \\
\text { water stream }\end{array}$ & \\
\hline $\begin{array}{l}\text { The cost of the heat energy removal in } \\
\text { the cooling water stream is saved }\end{array}$ & \\
\hline $\begin{array}{l}\text { The heating cost of the greenhouses is } \\
\text { low }\end{array}$ & \\
\hline $\begin{array}{l}\text { The capital cost of the heating system is } \\
\text { subsidized }\end{array}$ & \\
\hline
\end{tabular}

\section{Use of solar photovoltaic systems in greenhouses}

Solar photovoltaic systems can be used for electricity generation in greenhouses. There are two important reasons that currently allow their use

A) The sharp drop in solar panel's prices during the last years, and

B) The net-metering regulations that allow the generation of solar electricity in grid connected greenhouses in order to compensate annually the grid electricity consumption.

Particularly in countries with high solar irradiance like in Mediterranean countries their use is attractive and challenging. However their use in non-grid connected greenhouses is expensive due to the high cost of electricity storage in batteries. Recent advances in semi-transparent solar-PVs permit their use in roof-tops of greenhouses although their prices are still high. The use of solar energy, like other sustainable energy technologies, in greenhouses lowers their carbon emissions due to energy use. Advances and drawbacks of electricity generation with solar-PVs in greenhouses are presented in table 5. 


\section{Macrothink}

Table 5. Advances and drawbacks of electricity generation in greenhouses with solar-PVs.

\begin{tabular}{|l|l|}
\hline Advantages & Drawbacks \\
\hline $\begin{array}{l}\text { They can cover all the electricity needs in } \\
\text { greenhouses }\end{array}$ & $\begin{array}{l}\text { Their use is only economically feasible in } \\
\text { areas with high solar irradiance }\end{array}$ \\
\hline $\begin{array}{l}\text { Their use in areas with high solar } \\
\text { irradiance is economically attractive }\end{array}$ & $\begin{array}{l}\text { Their use requires an additional capital } \\
\text { investment }\end{array}$ \\
\hline $\begin{array}{l}\text { Their use results in the decrease of the } \\
\text { operating cost in greenhouses }\end{array}$ & $\begin{array}{l}\text { The cost of semi-transparent solar-PVs is } \\
\text { still high }\end{array}$ \\
\hline $\begin{array}{l}\text { Their use reduces the carbon emissions } \\
\text { due to energy use in greenhouses }\end{array}$ & $\begin{array}{l}\text { Their use is more suitable in grid } \\
\text { connected greenhouses }\end{array}$ \\
\hline
\end{tabular}

Various characteristics of the abovementioned sustainable energies which can be used in greenhouses in Greece are presented in table 6.

Table 6. Characteristics of sustainable energies which can be used in greenhouses in Greece.

\begin{tabular}{|l|l|l|l|l|}
\hline Technology & $\begin{array}{l}\text { Primary } \\
\text { energy } \\
\text { source/fuel }\end{array}$ & Final energy & $\begin{array}{l}\text { Covering of energy } \\
\text { needs }\end{array}$ & $\begin{array}{l}\text { Greenhouse gas } \\
\text { emissions }\end{array}$ \\
\hline $\begin{array}{l}\text { Heating with } \\
\text { direct geothermal } \\
\text { fluids }\end{array}$ & Geothermal & Heat energy & $\begin{array}{l}\text { All the heating } \\
\text { needs }\end{array}$ & Usually no \\
\hline $\begin{array}{l}\text { Solid biomass } \\
\text { burning }\end{array}$ & Biomass & Heat energy & $\begin{array}{l}\text { All the heating } \\
\text { needs }\end{array}$ & $\begin{array}{l}\text { There are not net } \\
\text { emissions }\end{array}$ \\
\hline $\begin{array}{l}\text { Co-generation of } \\
\text { heat and power }\end{array}$ & $\begin{array}{l}\text { Natural gas or } \\
\text { biomass }\end{array}$ & $\begin{array}{l}\text { Heat energy } \\
\text { and } \\
\text { electricity }\end{array}$ & $\begin{array}{l}\text { All the heating } \\
\text { needs electricity } \\
\text { surplus can be sold } \\
\text { into the grid }\end{array}$ & $\begin{array}{l}\text { The } \\
\text { emissions if } \\
\text { natural gas is } \\
\text { used hed }\end{array}$ \\
\hline Waste heat re-use & Rejected heat & Heat energy & $\begin{array}{l}\text { All the heating } \\
\text { needs }\end{array}$ & $\begin{array}{l}\text { There are not } \\
\text { emissions }\end{array}$ \\
\hline Solar-PV panels & Solar energy & Electricity & $\begin{array}{l}\text { All the electricity } \\
\text { needs and the } \\
\text { surplus can be sold } \\
\text { into the grid }\end{array}$ & $\begin{array}{l}\text { There are not } \\
\text { emissions }\end{array}$ \\
\hline
\end{tabular}




\section{Environmental and social benefits from the use of sustainable energies in greenhouses}

Currently the energy needs of greenhouses are usually covered with fossil fuels creating environmental deterioration. The use of sustainable energies in greenhouses will result in many environmental benefits. It will reduce the use of fossil fuels and carbon emissions and it will increase the use of renewable energies in them, contributing in the fulfilment of EU targets for mitigation of climate change. In countries where oil and natural gas are imported it will reduce the dependence on fossil fuels. The use of indigenous renewable energies will increase local employment and energy investments promoting the prosperity in the local societies. Due to many environmental, social and economic benefits their use should be financially subsidized and existing barriers hindering their applications should be removed.

\section{Discussion and Conclusions}

Promotion of sustainable agriculture requires the use of environmental friendly technologies including the use of sustainable energies. Modern agricultural greenhouses require large energy inputs for maintaining the optimum indoor conditions for the growth of crops. Currently there are various renewable energy technologies which are mature, reliable and cost effective which could be used for power or/and heat generation in greenhouses. They have been realized in various greenhouses globally with positive and encouraging results. They include the use of geothermal energy, solid biomass, solar photovoltaic panels, co-generation of heat and power and the re-use of industrial waste heat. Some of them are already used in modern greenhouses producing vegetables in Greece mainly for heat generation. They include the use of geothermal energy, solid biomass and co-generation systems. However their use is rather limited and they could find broad applications in the near future. The prospects of using other technologies which are not used today like solar-PVs and waste heat re-use in Greece are positive. Current EU policies promote the reduction of carbon emissions and the increase of renewable energies use in all sectors of the economy including in agriculture. They also promote the circular economy, the recycle of matter and energy and the transition to low carbon agriculture. The use of the abovementioned sustainable energy technologies in agricultural greenhouses in Greece results in many environmental, economic and social benefits. Therefore the various barriers which currently exist and limit the use of those technologies should be removed in order to promote their higher future use in the agricultural sector.

\section{References}

Bakos, G.C., Fidanidis, D. \&Tsagas, N.F. (1999).Greenhouse heating with geothermal Energy, Geothermics, 28, 759-765. http://dx.doi.org/10.1016/s0375-6505(99)00041-3

Bibbiani, C., Fantozzi, F. Gargari, C., Campiotti, C.A., Schettini, E. \& Vox, G. (2016). Wood biomass as sustainable energy for greenhouses heating in Italy, Agriculture and Agricultural Science Procedia, 8, 637-645. doi 10.1016/j.aaspro.2016.02.086.

Bredenbeck, H. (1992). The use of waste heat from a power plant for greenhouse heating in commercial application in Germany, Acta Horticulturae, 312, 29-35. 
Campiotti, C.A., Viola, C., Alonzo, G., Bibbiani, C., Giagnacovo, G., Scoccianti, M. \&Tumminelli, G. (2012). Sustainable greenhouse horticulture in Europe, Journal of Sustainable Energy, 3(3), 1.

Chau, J., Sowlati, T., Sokhansanj, S., Preto, F., Malin, S. \& Bi, X. (2009).Techno-economic analysis of wood biomass boilers for the greenhouse industry, Applied Energy, 86, 364-371. doi:10.1016/j.apenergy.2008.05.010

Compernolle, T., Witters, N., Van Passel, S. \&Thewys, T. (2011). Analyzing a self-managed $\mathrm{CHP}$ system for greenhouse cultivation as a profitable way to reduce $\mathrm{CO}_{2}$-emissions, Energy, 36, 1940-1947. doi:10.1016/j.energy.2010.02.045

Dion, L.M., Lefsrud, M. \&Orsat, V. (2011).Review of $\mathrm{CO}_{2}$ recovery methods from the exhaust gas of biomass heating systems for safe enrichment in greenhouses, Biomass and Bioenergy, 35(8), 3422-3432. doi:10.1016/j.biombioe.2011.06.013

Esen, M. \&Yuksel, T. (2013).Experimental evaluation of using various renewable energy sources for heating a greenhouse, Energy and Buildings, 65, 340-351.

doi :10.1016/j.enbuild.2013.06.018

Garcia, J.L., La Plaza, S.D., Navas, L.M., Benavente, R.M. \& Luna, L.(1998). Evaluation of the feasibility of alternative energy sources for greenhouse heating, Journal of Agricultural Engineering Resources, 69, 107-114. doi:10.1006/jaer.1997.0028

Gousgouriotis, I.J., Katsigiannis, Y.A. \&Georgilakis, P.S. (2007). Economic evaluation of biomass heating systems: a case of greenhouses in northern Greece, Operational Research. An International Journal, 7(1), 37-58.

Kittas, K., Giaglaras, P. \&Koutra, A. (2002). Greenhouse heating with biomass in the Prefecture of Magnesia, Proceedings of the $7^{\text {th }}$ National conference for RES, Patra, 6-8 November 2002, Volume 2 , p. 1690176, (in Greek).

Maare, O., (1992). Economical Heat Supply of Greenhouses Experiences from Denmark, Acta Horticulturae, (ISHS) 312, 37-44.

Manning, T.O. \& Mears, D.R. (1983). Engineering performance of a 1.1 hectare waste-heated greenhouse, presented in the summer meeting of the American Society of Agricultural Engineers,Montana State University, Bozeman, Montana, 26-29 June 1983.

Marucci, A., Monarca, D., Cecchini, M., Colantoni, M., Manzo, A. \& Cappuccini, A. (2012). The semi-transparent photovoltaic films for Mediterranean greenhouse: A new sustainable technology, Mathematical Problems in Engineering, 2012, 1-14.

http://dx.doi.org/10.1155/2012/451934

Papachristou, M., Mendrinos, D., Dalampakis, P., Arvanitis, A., Karytsas, C., \&Andritsos, N. ( 2016, September). Geothermal energy use, Country update for Greece, European geothermal congress 2016, Strasbourg, France, 19-24 September 2016, p. 1-14.

Santamouris, M., Mihalakopoulou, G., Balaras, C.A., Argiriou, A., Asimakopoulos, D. 


\section{Macrothink}

Journal of Agricultural Studies

ISSN 2166-0379

2018, Vol. 6, No. 2

\&Vallindras, M. (1995).Use of buried pipes for energy conservation in cooling of agricultural greenhouses, Solar Energy, 55, 111-124. http://dx.doi.org/10.1016/0038-092x(95)00028-p

Tudisca, S., Di Trapani, A.M., Sgroi, F., Testa, R. \&Squatrito, R. (2013). Assessment of Italian energy policy through the study of a photovoltaic investment on greenhouse, African Journal of Agricultural Research, 8(24), 3089-3096. http://dx.doi.org/10.5897/AJAR 2013.7406

Vourdoubas, J. (2015). Overview of heating greenhouses with renewable energy sources. A case study in Crete-Greece, Journal of Agricultural and Environmental Sciences, 4(1), 70-76. doi: 10.15640/jaes.v4n1a9

Vourdoubas, J. (2016). Overview of the use of sustainable energies in agricultural greenhouses, Journal of Agricultural Science, 8(3), 36-43. doi:10.5539/jas.v8n3p36

Vourdoubas, J. (2016). Possibilities of using semi-transparent photovoltaic modulus on rooftops of greenhouses for covering their energy needs, Journal of Agricultural Studies, 4(1), 90-100. doi:10.5296/jas.v4i1.8694

Vourdoubas, J. (2018). Possibilities of using industrial waste heat for heating greenhouses in Northern Greece, Journal of Agricultural Science, 10(4), 116-123, doi:10.5539/jas.v10n4p116.

\section{Copyright Disclaimer}

Copyright for this article is retained by the author(s), with first publication rights granted to the journal.

This is an open-access article distributed under the terms and conditions of the Creative Commons Attribution license (http://creativecommons.org/licenses/by/4.0/). 